\title{
POULTRY LITTER: A SUSTAINABLE ENERGY AND AGRICULTURAL RESOURCE OF BANGLADESH
}

\author{
Md. Khayrul Alam Bhuiyan' \\ Kazi Farhed Iqubal ${ }^{2}$ \\ Md. Eftekhar Hossain ${ }^{2}$ \\ ${ }^{\prime}$ Forest Department, Dhaka Forest Division, Bangladesh \\ ${ }^{2}$ State University of Bangladesh, Bangladesh
}

\begin{abstract}
Poultry litter has been creating nuisance in Gazipur district of Bangladesh over the last two decades. It could be a good source of biogas and fertilizer if managed properly. An attempt was made for the recycling of poultry litter through this study. The 300 million poultry birds produce 18,000 metric tons (MT) of litter daily and if processed, it could generate 1.4 million $\mathrm{m}^{3}$ of biogas in Bangladesh. The Gazipur district produces 1,600 MT poultry litter per day and consequently this corresponds to 0.12 million $\mathrm{m}^{3} / \mathrm{d}$ of biogas

from which $7 \mathrm{MW}$ electricity can be produced daily. This gas can be used for cooking, poultry house heating and electricity generation. On the other hand, the slurry as the byproduct of poultry litter has a potential value to be used as fertilizer which can meet macro and micro nutrients demand of soil for crop production. The constituent of fertilizer are $16.69 \%$ organic matter, $11.17 \%$ moisture, $2.73 \%$ nitrogen, $3.29 \%$ phosphorus, $0.85 \%$ potassium, $1.00 \%$ sulfur, $4.50 \%$ calcium, $2.52 \%$ magnesium, $0.21 \%$ ferrous, $0.067 \%$ manganese, $0.041 \%$ boron, $0.034 \%$ zinc, $0.006 \%$ copper, etc.
\end{abstract}

\section{KEY WORDS}

Poultry litter; Biogas; Slurry; Fertilizer.

\section{INTRODUCTION}

Bangladesh is one of the countries with subtropical monsoon climate and is a potential source zone of biomass generation. Use of wood, rice straw and cow dung as fuel is causing deforestation, loss of biodiversity and soil fertility. Due to increase of population, fuel crisis in the country is increasing at increasing rate; it will be more acute when the reserve of natural gas will be exhausted. Biogas energy may be considered as effective source of alternate energy. Overall climatic conditions (temperature, humidity, etc.) of Bangladesh is very suitable (except few days/night, during winter) for biogas production. Also there is a worldwide potential of biogas including neighboring countries. India produces biogas equivalent to $17,000 \mathrm{MW}[1]$.

The first KVIC model floating-drum biogas plant was constructed in 1972 at the premises of Bangladesh Agriculture University (BAU) for research and study purposes. Later, BCSIR, DANIDA, LGED, DLS, MATI, Grameen Sakti and other development agencies constructed either floating-drum or fixed-dome plants throughout the country. Initially the raw material or 
feed materials were animal dung or night soil. Poultry litter is a potential raw material for anaerobic digestion. Using poultry litter as a feed material is a new invention for Bangladesh. Implementing biogas plant is technically, economically and financially feasible for Bangladesh [2].

Biogas can be used for other purposes such as electricity generation, refrigeration, space heating and running engines but higher amount of gas will be required for these purposes. Family size (up to $9 \mathrm{~m}^{3}$ ) biogas plant is appropriate only for the domestic use such as cooking and lighting.

Energy sources in Bangladesh can be broadly classified into three categories: a) traditional b) commercial and c) renewable. Traditional energy (biomass) includes fuel wood, agricultural residues, leaves and dried dung cake. It is estimated that about $55 \%$ of the country's energy is met through traditional energy sources. Most of them are used for cooking. Excessive use of biomass energy may already exceed the regenerative limit and there prevails energy crisis in rural areas [3]. An estimated total amount of traditional fuels (biomass) supplied in the year 2002-2003 was approximately 11,199 million tons of coal equivalent. Table 1 presents the traditional energy supply by source.

Table 1. Traditional energy supplied in 2002-2003 [4].

\begin{tabular}{lrr}
\hline Fuel source & Tones of coal equivalent & Percentage \\
\hline Rice hulls & 2,926 & 26.1 \\
Cattle dung & 2,112 & 18.9 \\
Rice straw & 1,668 & 14.9 \\
Twigs and leaves & 1,536 & 13.7 \\
Firewood & 629 & 5.6 \\
Bagasse & 612 & 5.4 \\
Jute stick & 453 & 4.0 \\
Other wastes & 1,281 & 11.4 \\
\hline Total & 11,199 & 100 \\
\hline
\end{tabular}

Bangladesh requires around $5,000 \mathrm{MW}$ of electricity but its production capacity staggers between 3,000 MW and 3,300 MW, depending on the condition of its decades-old power plants.

The potential consumers of electricity are large and medium industry, small and cottage industry, households, commercial areas. Due to continuous shortage of electricity supply large and medium industry and commercial areas could partially fulfilled their electricity demand by installing diesel or gas based generator. Very few urban household has met this demand by using IPS and diesel generator. But small and cottage industries and the rest of the urban and rural household severely lack of meeting electricity demand. Use of biogas for cooking and electricity may fulfill this energy demand in the study area. To meet the crisis it is an urgent need to search for alternative energy source in Bangladesh and biogas could be one of the sustainable energy solutions. 


\section{OBJECTIVES}

The general objective of this study is to find a suitable solution of poultry litter which is creating nuisance in the Gazipur district. The specific objectives are to find the opportunity of biogas production in the study area and to find the use of byproduct of the biogas plant.

\section{METHODOLOGY}

The investigation about poultry waste generators and its neighboring groups were conducted in 2006. The institutional data were gathered from District Livestock Office, Gazipur and other private and community-based organizations. In addition, key-person interviews and field observations were used. The secondary data and information used in this study were collected from various sources. In addition, published materials in the form of books, journals, magazines, newspapers and some unpublished reports were consulted in developing a conceptual framework for this study.

\section{RESULTS AND DISCUSSION}

Gazipur district is situated in the northern part of Dhaka, a mega city. As an urban fringe, this district has been developed with medium, small and cottage industries. Poultry industrial development in this district is remarkably good. Figure 1 shows the distribution of poultry hatchery, broiler and layer farm in Gazipur district.

In the last two decades, poultry farm having sizes ranging from a few hundred birds to several hundred thousand birds are mushrooming throughout the country. According to the last estimate of the Department of Livestock, Gazipur, the total number of hatchery and breeder farm is 136 , of which each contains more than 0.1 million birds. In total 300 million birds are being nurtured in 0.15 million farms in Bangladesh. Most of the hatchery is situated in Gazipur. On an average there are about $27,000,00$ birds are being nurtured in 16,000 farms (farm size: $200+$ birds).

According to our present research it is estimated that 1000 birds (mean of broiler, layer and cock) generate $60 \mathrm{~kg}$ dropping (wet weight) every day. Thus, the 300 million birds can generate $18,000 \mathrm{MT} / \mathrm{d}$ of dropping in Bangladesh. It is possible to produce 1.4 million cum gas or $50 \mathrm{MW}$ of electricity from the waste produce each day and 1.5 million MT organic fertilizers per year.

In the study area, almost $80-90 \%$ of poultry droppings are dumped in the open air and the uncontrolled transportation of those droppings often create environmental hazard, public nuisance, health hazard, surface and ground water pollution. As the poultry waste remains in the anaerobic condition in biogas plant for 30-40 days, all its germs die and slurry becomes pathogen free. 


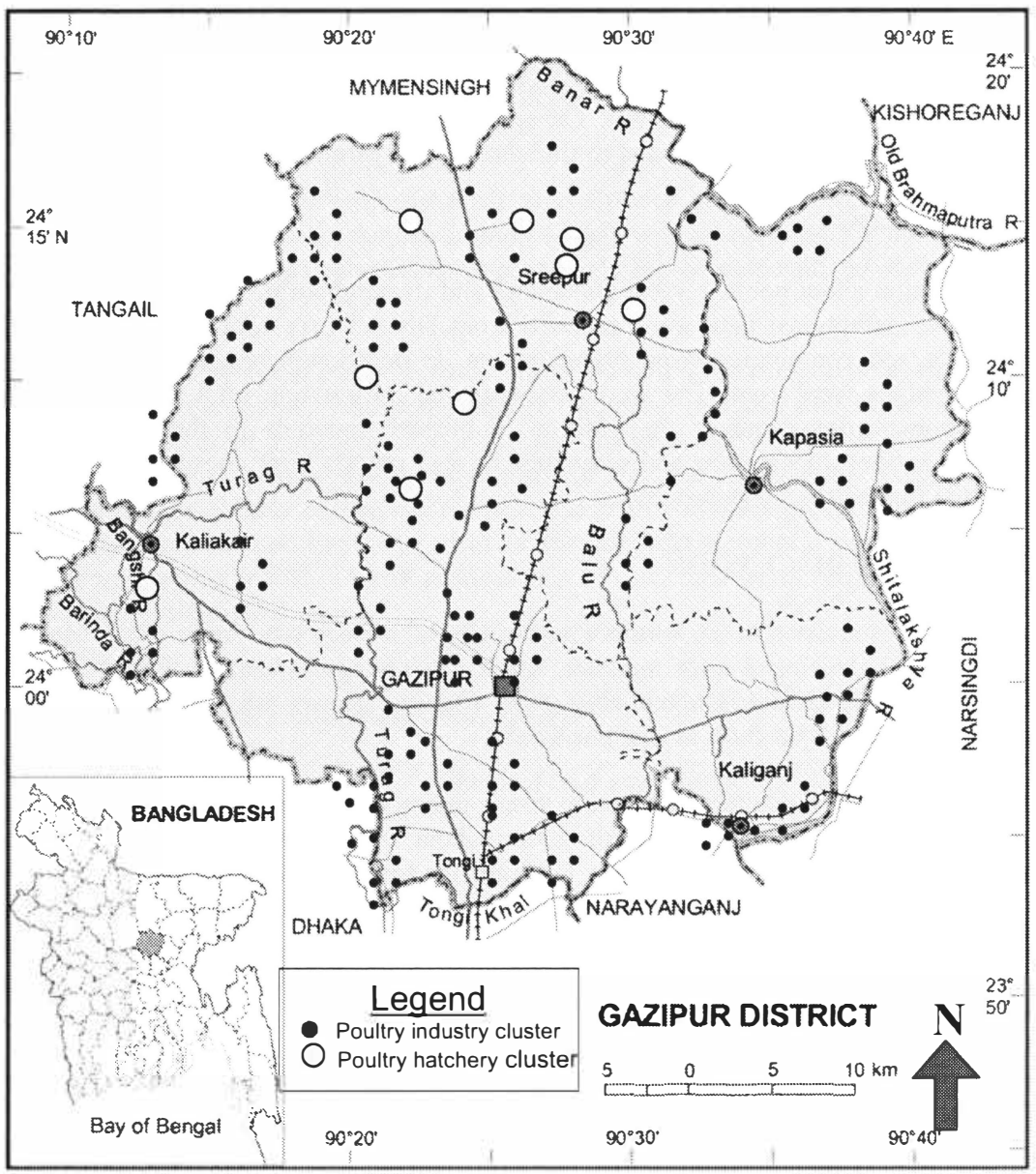

Figure 1. Spatial distribution of poultry industries in different upazillas of Gazipur district.

Table 2 shows poultry litter generation from 1,000 poultry bird species wise. The mean poultry (broiler, layer and cock) liter is about $60 \mathrm{~kg}$ per bird per day.

Table 2. Generation of poultry litter according to the bird species [5].

\begin{tabular}{ccc}
\hline S1 No & Bird species & $\begin{array}{c}\text { Mean waste generation per } 1000 \text { birds } \\
\text { (wet weight) in } \mathrm{kg}\end{array}$ \\
\hline 1 & Broiler & 47.0 \\
2 & Layer & 69.1 \\
3 & Cock & 64.2 \\
\hline & Mean & 60.1 \\
\hline
\end{tabular}


Table 3 shows different type of biogas plant according to biogas production and feed materials (poultry litter). On an average $12.80 \mathrm{~kg}$ litter is required for the generation of $1 \mathrm{~m}^{3}$ of biogas.

Table 3. Size of biogas plant with requirement of raw materials (poultry litter) [5].

\begin{tabular}{ccc}
\hline Type & $\begin{array}{c}\text { Size of biogas plant } \\
\left(\mathrm{m}^{3}\right)\end{array}$ & $\begin{array}{c}\text { Mean waste needed per } \mathrm{m}^{3} \text { of biogas } \\
(\mathrm{kg})\end{array}$ \\
\hline 1. & 3 & 13.67 \\
2. & 6 & 12.87 \\
3. & 9 & 11.88 \\
\hline & Mean & 12.80 \\
\hline
\end{tabular}

Table 4 shows an estimated biogas production in Gazipur district. The Gazipur district which generates 1,600 MT poultry litter per day (at $60 \mathrm{~kg}$ of droppings/bird/d) produces 0.12 million $\mathrm{m}^{3}$ biogas per day (at $12.80 \mathrm{~kg} / \mathrm{m}^{3} / \mathrm{d}$ ). From which $7 \mathrm{MW}$ electricity can be produced daily.

Table 4. Estimated biogas production in Gazipur district compared to Bangladesh.

\begin{tabular}{lllll}
\hline Study area & Number of birds & $\begin{array}{l}\text { Poultry litter } \\
\text { production } \\
(\mathrm{MT} / \mathrm{d})\end{array}$ & $\begin{array}{l}\text { Biogas production } \\
\left(\text { Million } \mathrm{m}^{3} / \mathrm{d}\right)\end{array}$ & $\begin{array}{l}\text { Electricity } \\
\mathrm{MW} / \mathrm{d}\end{array}$ \\
\hline Gazipur & $27,000,000$ & 1,600 & 0.12 & 7 \\
Bangladesh & $300,000,000$ & 18,000 & 1.40 & 50 \\
\hline
\end{tabular}

Biogas construction helps the management of poultry waste. The surroundings become clean, healthy and odor free if biogas plant is constructed in poultry farms. It is estimated that about 116,000 poultry farms are in operation in Bangladesh that are spreading bad smells in and around the community. Recycling of poultry litter through installation of biogas plant is now improving the surrounding environment.

The amount of organic matter in the soil is one of the best indicators representing soil quality. The concentration of soil organic materials in the country has been deteriorating over the last few decades. Presently, over $50 \%$ of the agricultural land is below the critical level. The highest deterioration of organic materials has been found in the Barind Tract, Madhupur Tract, Himalayan Foothill areas, the floodplains of Tista, Karatoya and Bangaii, and in the northeast hilly region. Moderate deterioration of organic materials has been observed in medium highlands of the rivers Tista, the Jamuna and in the Ganges floodplain [6].

The Soil Resources Development Institute (SRDI) has analyzed soil samples, and found that nitrogen deficiency is common all over the country. The Sylhet haor areas, Surma-Kushiyara floodplain, northeast hilly area and Madhupur Tract have a noticeably intense deficiency of Phosphorus. Deficiency of other chemical substances has also been noticed in other parts of the country. As shown in Table 5 the level of organic matter in the soil of Bangladesh is very low. About $45 \%$ of the net cultivable area (NCA) of the country has less than $1 \%$ of organic matter content. 
Table 5. Organic matter status of Bangladesh soils [7].

\begin{tabular}{|c|c|c|c|}
\hline $\begin{array}{l}\text { Class of organic } \\
\text { matter }\end{array}$ & Main locations & $\begin{array}{l}\text { Total area } \\
\text { (Mha) }\end{array}$ & $\% \mathrm{NCA}$ \\
\hline Very low $(<1.0 \%)$ & $\begin{array}{l}\text { Dinajpur, Sherpur, Jamalpur, Tangail, } \\
\text { Gazipur, Nawabganj, Rahshahi, Pabna, } \\
\text { Kushtia, Bogra, Naogaon, Rangpur, } \\
\text { Khagrachari, Bandarban and Chittagong }\end{array}$ & 4.05 & 44.5 \\
\hline Low (1.0-1.7\%) & $\begin{array}{l}\text { Adjoining area of Tista, Dharlus, } \\
\text { Chandpur, Lakshimipur, Noakhali, Bhola, } \\
\text { Barisal, Patuakhali, Narsingdi and Dhaka }\end{array}$ & 1.56 & 17.1 \\
\hline Medium (1.7-3.5\%) & $\begin{array}{l}\text { Sirajganj, Mymensingh, Kishoreganj, } \\
\text { Sherpur, Jamalpur, Sylhet, Moulvibazar, } \\
\text { Feni and Cox's Bazar }\end{array}$ & 1.94 & 21.3 \\
\hline High $(>3.5 \%)$ & $\begin{array}{l}\text { Panchaghar, Natore, Naogaon, Khulna, } \\
\text { Satkhira, Madaripur, Gopalganj, } \\
\text { Munshiganj, Habiganj, Sunamganj and } \\
\text { Netrokona }\end{array}$ & 1.56 & 17.1 \\
\hline
\end{tabular}

Organic matter content of the soil should be maintained at least $3 \%$, but due to over exploitation for HYV crop and use of uncontrolled inorganic fertilizer, organic matter of soil of Bangladesh is depleted and declined alarmingly low around $1 \%-2 \%$ [8]. If this extent goes less than $0.5 \%$, crop will not grow, even if we ensure the highest dose of chemical fertilizer. The quality of organic fertilizer produced from poultry waste is $20-30 \%$ higher than that of compost or cow dung. It is possible to produce 1.5 million MT of organic fertilizer per year from poultry waste by installing biogas plant in each poultry farm.

According to the present context of Bangladesh, there is no need to import raw materials needed for biogas technology. The proper management of poultry waste can ensure clean fuel, community electricity, healthy and fresh environment and high quality organic fertilizer.

Biogas is a reliable, easy and very useful source of household energy; hence, it is also a stable source of energy. Biogas has several benefits. These benefits are the main motivating factors of rural households towards adoption of biogas. It brings gender benefits by reducing workload of rural women, environmental benefits by improving indoor air quality and reducing considerable amount green house gases, health benefits by improving child and mother health, decreasing pathogen contamination and economic benefits by reducing expenses on fuel for cooking, quick plant cost recovery by selling gas and organic manure.

The use of agriculture and animal waste for cooking purposes rather than as an organic fertilizer has adverse effect on maintaining the soil fertility, thereby reducing crop production and land productivity. In order to prevent further environmental and agricultural deterioration, it is imperative to promote new sources of energy technologies in Bangladesh. Among the other potential alternative sources of rural energy, biogas produced from dung is undoubtedly one of the most appropriate sources of energy for the rural areas of Bangladesh. It can have two folds benefits as household cooking energy; and as high quality fertilizer. 
Table 6. Nutrient constituents in poultry fertilizer.

\begin{tabular}{lc}
\hline Nutrient & Composition $(\%)$ \\
\hline Copper & 0.006 \\
Zinc & 0.034 \\
Boron & 0.041 \\
Manganese & 0.067 \\
Ferrous & 0.21 \\
Potassium & 0.85 \\
Sulfur & 1.00 \\
Magnesium & 2.52 \\
Nitrogen & 2.73 \\
Phosphorus & 3.29 \\
Calcium & 4.50 \\
Moisture & 11.17 \\
Organic matter & 16.69 \\
Residues & 56.89 \\
\hline
\end{tabular}

On the other hand, the slurry as the byproduct of poultry litter has a potential value (Table 6) as fertilizer which can meet macro and micro nutrients demand of soil for crop production. The constituent of fertilizer are $16.69 \%$ organic matter, $11.17 \%$ moisture, $2.73 \%$ nitrogen, $3.29 \%$ phosphorus, $0.85 \%$ potassium, $1.00 \%$ sulfur, $4.50 \%$ calcium, $2.52 \%$ magnesium, $0.21 \%$ ferrous, $0.067 \%$ manganese, $0.041 \%$ boron, $0.034 \%$ zinc, $0.006 \%$ copper, etc. Farmers need not to use extra sulfur, phosphorous, boron, zinc and copper buster fertilizer if they use poultry fertilizer. It also act as insect repellant.

\section{CONCLUSIONS}

The anaerobic digestion of poultry waste produces combustible biogas by preserving nutrients that help to improve the soil fertility. The application of this technology in rural areas in developing countries would provide an excellent renewable source of clean energy and biofertilizers and improve environmental sanitation, thereby protecting human health and the environment. Thus, biogas technology appears to be a sustainable system for the management of poultry waste in the developing world in general and Bangladesh in particular.

\section{ACKNOWLEDGEMENT}

The assistance and help of the Multipurpose Attractive and Trustee Initiatives (MATI) and Center for Environmental Studies (CES) are greatly acknowledged by the authors during research work.

\section{REFERENCES}

[1] Tata, 1998. Tata energy data and directory yearbook, 1997/8. Tata Energy Research Institute, New Delhi.

[2] SNV/IDCOL, 2005. Technical Study of Biogas Plants Constructed in Bangladesh. (Draft report) October 2005 
[3] Asaduzzaman, M., Latif, A. 2005. Study report on energy for rural households"Towards a Rural Energy Strategy in Bangladesh" prepared for World Bank.

[4] BBS, 2003. Statistical pocket book of Bangladesh 2001, Planning Division, Ministry of Planning, Dhaka, Bangladesh.

[5] Gofran, M.A., 2004. Biogas Projuction (The Biogas Technology), Dhaka, Bangladesh.

[6] Karim, Z., Mia, M.M.U., Razia, S., 1994. Fertilizer in the National Economy and Sustainable Environmental Development, Asia Pacific Journal of Environment and Development, 1 (2), 48-67.

[7] BARC, 1999. Land Degradation Situation in Bangladesh. Soil division, Bangldesh Agricultural Research council. Dhaka Bangladesh.

[8] Islam, M. S., 2006, Use of Bio slurry as organic fertilizer in Bangladesh agriculture, Grameen Shakti, Dhaka. (Paper presented in the international workshop on the use of bioslurry, domestic biogas program, Bangkok, Thailand. 